\title{
The effects of work resources and career adaptability on employee health: A case of sample of teachers in South Africa
}

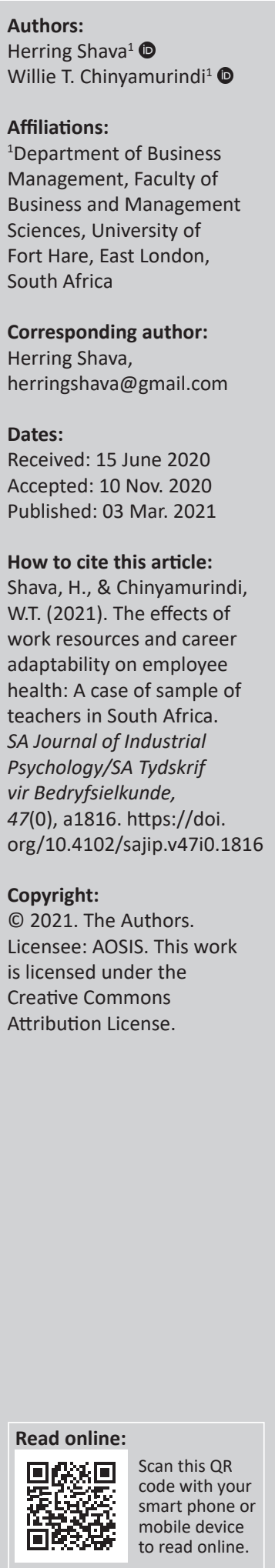

Orientation: There is a rise in health-related challenges within the confines of the organisation. Strategies are needed not just from a human resources practitioner but also a theoretical basis in finding solutions to such challenges.

Research purpose: Firstly, to determine the effects that work resources have on employee health and its two facets of physical and mental health. Secondly, to determine if career adaptability moderates the relationship between work resources and employee health.

Motivation for the study: Studies exist in the literature that focus on the intersection of individual and organisational factors on health constructs such as mental health. Further, such studies continue to be an issue of inquiry especially within the public service professions such as teaching.

Research approach/design and method: A quantitative research approach utilising a survey data collection technique was utilised. Simple linear regression and a hierarchical regression were performed to analyse the data.

Main findings: Work resources do predict employee mental and physical health. Further, career adaptability does not moderate the relationship between work resources and employee health among teachers.

Practical/managerial implications: Based on the findings, recommendations are made that assist not just teachers but also those engaged in creating a context in which teachers can thrive from a management perspective.

Contribution/value-add: The findings help us focus on the notion that in rural high schools of South Africa, a supportive work environment for assisting teachers to utilise work resources for organisational functioning, in a manner that is friendly to their mental and physical health is needed.

Keywords: work resources; career adaptability; employee health; mental health; physical health; public service.

\section{Introduction}

The world of work is changing. Much of this change is attributed to the uncertainty and turbulence happening in the macro-environment and subsequently affecting the experience of work (Cooke, 2018; Psychogios \& Prouska, 2019). The situation is exacerbated by the rapid technological advancement that in some cases not only poses a threat but also potentially can be an opportunity for the world of work (Bondarouk, Parry, \& Furtmueller, 2017). Within all this, there is evidence showing the value that is being placed on a balancing act between work and home life (Bhave \& Lefter, 2017).

A key response to the many changes happening is the need to continuously support and develop employees albeit the uncertainty (Jehanzeb, 2020; Watson, 2009) and this positions the need for human resources (HR) professionals who are able to provide this service to their workforce (Mburu, 2020; Stone \& Dulebohn, 2013). A number of interventions have also been proposed in the literature to try and assist workers adjust to the many changes. Some studies call for a re-think about issues of where employees work to start considering a multi-layer of combinations that accommodate the office, home or spaces where people are commuting (Kossek \& Lautsch, 2018). Others studies allude to the potential role that technology can have on the experience of work, such as digitalisation and artificial intelligence (Mazmanian, Orlikowski, 
\& Yates, 2013; Orlikowski \& Scott, 2014). This is supported by the use of HR analytics which is potentially assisting in how decisions can be made with regard to the human capability of the organisation (Fieseler, Bucher, \& Hoffmann, 2019).

As the experience of work changes, there is the need to be aware that these changes can have a toll not only on the attitudes developed but also affecting aspects such as performance and employee well-being (Cañibano, 2019). The thinking here is that despite the changes which are being introduced that affect employees, these changes induce different types of responses across varying experiences and circumstances (Avgoustaki \& Frankort, 2019). Variation potentially exists not only by the type of work but also the type of organisation including the organisational and even national culture (Chung \& Tijdens, 2013). This calls for the necessity of leaders within organisations to be responsive to the challenges that can potentially affect both the experience of work and those engaged in work, the employees (Fountaine, McCarthy, \& Saleh, 2019). To ensure this type of response requires the development of HR practitioners' competencies to keep them abreast with the need and necessity for change by enabling them to show empathy towards their workforce (Tarafdar, Beath, \& Ross, 2019).

The conservation of resources (COR) theory as developed by Hobfoll (1989) and further elaborated in Hobfoll (2002) points out that resources are objects, things and conditions that people value. These may include quests for career development especially in response to a context that is not only uncertain but also undergoing rapid change (Johnston, 2018). Others frame quests for financial gain as very important (Odle-Dusseau et al., 2019). This may be true especially given that financial issues remain one of the leading causes of stress (Meuris \& Leana, 2018), resulting in this resource being one that is most sought after in organisations (Guo, Baruch, \& Russo, 2017). A plethora of other work resources exist that include (but not limited to): (1) self-esteem, (2) resilience, (3) social support, (4) autonomy, (5) job security and (6) emotional intelligence (Greenhaus \& Powell, 2006; Halbesleben et al., 2014; Ten Brummelhuis \& Bakker, 2012). In line with the COR, De Vos, Heijden and Akkermans (2018) argued that for careers to be sustained, there is a critical need to preserve and manage the resources required to pursue that career to its end. Generally, quests for attaining work resources have been linked to aspects of well-being (Cummins, 2000) that include mental and physical health (Guo et al., 2017). In line with the COR, this study pays critical attention to the element of conditions focusing on issues such as teacher salary, health insurance, performance bonus, housing and retirement allowances. Guo et al. (2017) and Cummins (2000) suggested that receiving work resources that are financial in nature relatively contribute to improved employee well-being, in the context of this study, that is, mental and physical health.

\section{Gaps in the literature}

We focus on understanding the challenge of employee health particularly on three fronts where this problem is magnified. Firstly, we note a global challenge of healthrelated issues affecting the contemporary world of work (Chinyamurindi, 2019). This includes aspects of physical health and especially mental health. Given the rise in healthrelated challenges within the confines of the organisation (Cooper, 2013), strategies are needed not just from a practitioner point of view but also by building from existing theories, viable solutions to such challenges may be found.

Secondly, we note that the challenges to be heightened especially within the public service in an organisational setting. Our research was located within the context of a South African public service, noted to be in a state of flux (Fihla \& Chinyamurindi, 2018) with employees being most affected. Ultimately, challenges faced by public service employees affect how they deliver service to the public (Mafini \& Dlodlo, 2014). Our focus for this study was on the teaching profession, classified as being part of the public service (Barling, Dupré, \& Kelloway, 2009). The need to understanding and address those factors that affect public employees such as teachers within the public service will influence the delivery of service to the public. (Kanyane, 2010; Thornhill \& Van Dijik, 2018). Further, empirical efforts are encouraged within the public service to ascertain those factors which are favourable or unfavourable that influence how public employees work (Ijeoma, Nzewi, \& Sibanda, 2013). We note the absence of work exploring organisational issues such as work resources linking this with employee health outcomes.

Thirdly, we note the need to be expansive in the way studies around employee health are conducted (Guo et al., 2017), especially bearing in mind issues of context, organisational culture, organisational setup and also national culture. We pay attention to understanding the role that work resources may have on aspects of employee health notably mental and physical health. We also extend from previous studies (Guo et al., 2017) by adding a moderator in career adaptability and ascertaining its influence not just on work resources but also employee health. The thinking here bears in mind the uncertain and changing world of work (Psychogios \& Prouska, 2019) in which employees can use career adaptability as a responsive activity for their career advancement (Savickas et al., 2009).

Maree (2017) added that career adaptability may be an important competence especially within the contemporary world of work. This can be in the form of re-planning, reconstructing and re-designing career plans in view of the changing environmental context (Rossier et al., 2017). Career adaptability is viewed as a critical factor for a person's career success, satisfaction and well-being, and career adaptability can also shield employees from work-related stress, thereby promoting employee health (Savickas \& Porfeli, 2012). We sought to ascertain within the South African public service if 
this is so. From these, implications for practice can also be made. The context of study we focus our attention on next is the teaching profession.

\section{The teaching profession in South Africa}

The teaching profession is deemed important especially within a South African context. Teachers form an important part in the process of nation-building especially considering the history of South Africa (Strydom et al., 2012). Yet it is also important to note that for some, especially in South Africa, entrance into the teaching profession may not have been because of the exercise of choice (Macupe, 2018). Career paths such as teaching were mostly the domain of the black populations, who could not exercise their career choice under the apartheid regime (Stead \& Watson, 2017). Yet teachers emerged as an important nation-building tool.

Despite this noted importance, Okeke and Dlamini (2013) assert that teachers face stresses emanating from individual, organizational and societal conditions. Examples include: (1) unfavourable teacher-learner ratios, (2) student-teacher bullying, (3) fellow teacher absenteeism, (4) constantly increasing administrative burdens, (5) diminished autonomy and finally (6) under-resourced classroom facilities (Ballet, Kelchtermans, \& Loughran, 2006; Pyhältö, Pietarinen, \& Salmela-Aro, 2011; Skaalvik \& Skaalvik, 2010; West \& Meier, 2020). These challenges ultimately impact service delivery outcomes (Mafini \& Dlodlo, 2014) potentially affecting the teachers and their contribution to service delivery (Shibiti, 2019; Redelinghuys \& Rothmann, 2020; Zondo, 2018).

Further, these identified stressors and challenges may also influence the teachers' professional identity (Schoeman \& Mabunda, 2012). The identified stressors also have a bearing not just on how teachers practise their profession but they also affect aspects of their own professional development (Esau, 2013). This places importance within the teaching profession in South Africa on not only monitoring but addressing those issues that affect the teacher's level of functioning and flourishing (Redelinghuys \& Rothmann, 2020). These could range from issues regarding teacher engagement (Hakanen, Bakker, \& Schaufeli, 2006) to issues that develop a teacher's experience of enthusiasm and satisfaction within their jobs (Roth et al., 2007).

\section{Literature review}

\section{Work resources and employee health}

Work resources are amongst key aspects that have an impact on employee health (Ilies et al., 2020). The empirical literature defined work resources as objects, things and conditions that individuals consider to be of material value (Hobfoll, 1989, 2002). According to Guo et al. (2017), work resources are critical to the daily upkeep of employees. Adopting the self-determination theory, we agree with the view that individuals have a set of basic psychological needs, for example autonomy, belonging and competence (Deci \& Ryan, 1985). Once the mentioned needs are fulfilled, they lead to a satisfying life thereby enabling employees to live healthily (Reis et al., 2000; Sheldon, Ryan, \& Reis, 1996). Schachtel (1954) also provided evidence that employee health tends to improve when they are in an environment that provides resources that fit their individual needs.

Research further provides evidence indicating that work support and other workplace activities are associated with employee happiness, well-being and positive work attitudes (Becchetti, Bruni, \& Zamagni, 2015; Boyd \& Nowell, 2020; Fisher, 2010). With regard to this, acquiring valuable resources at work can have positive implications for both personal and professional outcomes, for instance, employee health (Cummins, 2000; Hakanen, Peeters, \& Perhoniemi, 2011; McNall, Nicklin, \& Masuda, 2010; Ten Brummelhuis \& Baker, 2012). Existing literature describes the just-mentioned resources as extrinsic rewards which consist of pay, job security, benefits, promotions, raise in salary and bonuses (Jacobs, Renard, \& Snelgar, 2014). Hoole and Hotz (2016) concurred and pointed out that salary and bonuses fall under extrinsic rewards.

The worrying situation is that governments and many private entities are equally challenged to offer attractive compensation packages owing to poor economic growth, a trend in many African countries (Oginni \& Omoyele, 2018). Such work resources are critical in the sense that they help to satisfy an employee's primary physiological and psychological needs. Chege (2016) pointed out that regardless of the organisation type, once they take the responsibility to contribute health insurance for their employees, the satisfaction they derive from the organisation increases. Other factors such as enhanced employee health provide the impetus for employees to feel committed, engaged and valued (Lee, Rocco, \& Shuck, 2020). Additionally, retirement benefits enable employees to stay longer with the organisation (Otieno, 2010). Based on this discussion, Haider et al. (2015) argued that organisational leaders must do all within their power to ensure that they provide adequate work resources as it has many benefits, key amongst them being employee health. A healthy workforce leads to long-term profitability of the organisation. Given this discussion, the study hypothesises that:

H1: Work resources predict employee mental health.

H2: Work resources predict employee physical health.

\section{Career adaptability, work resources and employee health}

By definition, career adaptability is the (Savickas, 1997):

$[R]$ eadiness to cope with the predictable tasks of preparing for and participating in the work role and with the unpredictable adjustments prompted by the changes in work and work conditions. (p. 254)

Career adaptability comprises four psychosocial resources or transactional competencies, namely career concern, career 
control, career curiosity and career confidence (Koen, Klehe, \& Van Vianen, 2012; Savickas \& Porfeli, 2012).

Career adaptability and its four dimensions are anchored in the career construction theory (CCT) that seeks to explain the flexibility of individuals when it comes to dealing with changes and shifts at the workplace or in the career journey (Savickas, 2013). The CCT presents career adaptability as the overall individual preparedness to navigate career challenges and flourish on the same career path as aided by adaptability resources and competences.

As highlighted earlier, the four dimensions of career adaptability and related adaptive responses are proposed by the CCT and these are critical for career building. An absence of the four dimensions presents a myriad of challenges that result in career construction problems (Savickas, 2005, 2013). Firstly, people need to show concern about where they will end up being in the future as far as their career is concerned. This is vital to initiate the career planning process and ensuring individual relevance given the dynamic changes of the working environment, and work itself.

Secondly, people should feel that they are in control of their careers. This can be observed through individual decisions that clearly translate into tangible progress on their career path as a result of an individual's ability to be decisive as opposed to being indecisive. Thirdly, individuals should demonstrate curiosity and be able to explore information so that they can comprehend real events affecting their careers or the career environment. This ensures that they are prepared to handle such challenges when they materialise instead of suffering from unrealism (Flum \& Blustein, 2000). The fourth and final career adaptability dimension speaks of confidence. People with confidence are able to manage the career challenges coming their way and actively seek alternative measures to address the challenges instead of suffering from the career problem of inhibition (Savickas, 2013).

Based on the CCT, career adaptability refers to an employee's readiness to confront foreseen work-related challenges and also the preparedness to tackle the unknown work-related challenges that may arise owing to changes in work and working conditions (Lodi et al., 2020; Savickas, 1997). For an employee to able to do so, the adaptive resources namely, concern, control, curiosity and confidence must be activated (Johnston, 2018; Rossier, 2015; Savickas, 2013). South African rural teachers could be experiencing health-related challenges (mentally and physically), owing to poor work resources such as salary, performance bonus, health insurance, pension-related plans and any other form of allowances.

According to Mashaba and Maile (2018), teachers in South Africa's disadvantaged communities, which include rural areas, are poorly compensated. Empirical literature concurs and points out that South African teachers in disadvantaged communities receive poor work resources compared to those in South Africa's highly developed communities (Naicker, 2000). Literature that focuses on teacher absenteeism in South Africa points out that South Africa is a dualistic country: some areas of the country are highly developed and hence, the education system is advanced and well resourced (Bennell, 2004; Mashaba, 2014; Reddy, 2010; Reddy et al., 2010). Sadly, the same cannot be said about South Africa's education system in its disadvantaged communities, for example the rural areas. Using Zwane's (2020, p. 79) categorisation of South Africa's rural and urban areas, the author points out that the two are 'structurally very different, with different characteristics'.

The education system in rural areas is poorly maintained and it is characterised by poor working conditions, inadequate infrastructure with rural school teachers, who are predominantly blacks, earning $22.8 \%$ of what the white minority population earns (Statistics South Africa, 2011). Studies that also looked at the causes of teacher absenteeism and job dissatisfaction in Africa's low-income countries concurred with the notion that the education system in disadvantaged communities is characterised by low incentives (pay, bonuses amongst others), poor working conditions and limited infrastructure (Abeles, 2009; Ejere, 2010; Yiga \& Wandega, 2010). Mashaba and Maile (2018) further highlighted that poor compensation amongst rural teachers in South Africa stems from the country's macroeconomic policies. Although the growth, employment and redistribution (GEAR) macroeconomic policy framework has been side-lined after its adoption in 1996, Turok (2010) pointed out that its economic principles continue to dominate policy foundation in the country. Growth, employment and redistribution advocated for a decrease in public expenditure, which resulted in the government failing to address the education imbalances, including that of teacher compensation.

Zwane (2020) compared earnings between South Africa's urban and rural teachers relying on the National Income Dynamics data for the years 2008-2017. The study by Zwane (2020) revealed that an increase in a person's education qualification levels resulted in a corresponding increase in earnings equal to $37.8 \%$. Sadly, the study further reveals that the education impact on teachers' earnings is higher in absolute values for teachers in urban areas as they bagged $44.4 \%$ in total returns to education, compared to $33 \%$ for teachers in rural areas. Given that teachers in urban areas are benefiting more from education-related rewards compared to their rural counterparts, teachers in South Africa's rural areas could be experiencing mental and physical health-related challenges. However, this study argues that teachers in rural areas could overcome the mentioned challenges by activating career adaptability resources as proposed by the CCT (Johnston, 2018; Rossier, 2015; Savickas, 2013). Studies exist indicating that career adaptability predicts employee mental health (Xu et al., 2020). Career adaptability further plays the mental health protective role in adolescents 
(Ginevra et al., 2018). Given this discussion, the following hypotheses have been formulated:

H3: Career adaptability moderates the relationship between work resources and employee mental health.

H4: Career adaptability moderates the relationship between work resources and employee physical health.

\section{Methods}

The study is quantitative in nature and descriptive by design. A positivist research paradigm was adopted. Through a review of the theoretical literature, research hypotheses were formulated. A self-administered questionnaire was designed to gather quantitative data for the purposes of testing research hypotheses through statistical procedures. The study's research hypotheses remained unchanged until the end of this study.

\section{Measures}

The study's independent variable (work resources) was measured by a five-point Likert scale which had seven items. The scale had questions asking respondents whether the employer provided: (1) decent housing allowance, (2) a health insurance cover, (3) a decent life insurance cover, (4) decent retirement fund, (5) decent financial schemes in case of unemployment, (6) a competitive salary and (7) a competitive performance bonus. An example of the scale items reads, 'My employer provides supplementary health coverage for me'. This scale was codified 1-5, signifying 'strongly disagree' to 'strongly agree', respectively. The mentioned scale was developed and validated by Guo et al. (2017) and had a reliability score of 0.89. In this study, the reliability score was observed as 0.844 indicating that the scale was reliable and hence its adoption.

To measure the study's dependent variable (employee health), two dimensions were used, namely mental and physical health. The physical health sub-scale is made up of four items of the short Brief Pain Inventory developed by Cleeland and Ryan (1994). An example of the sample item reads, 'Did health issues interfere with your daily activities (e,g., walking or climbing upstairs)'? The scale has an internal consistence measure of Cronbach alpha equal to 0.89 . In this study, the reliability score of 0.80 was observed. A simplified Chinese Mental Health Inventory developed by $\mathrm{Wu}$ (1984) with five items was used to measure mental health. An example of a sample item from the stated scale reads, 'Were you bothered by any emotional issues (anxiety, depression or anger), last month'? Wu (1984) reported that the scale had a reliability score of 0.90. In this study, the reliability score was observed as 0.75 . Both physical and mental health scale items were measured on a five-point Likert scale codified 0-4, signifying 'none of the time' to 'all the time', respectively. A high the score on employee health indicated that the person had experienced either physical or mental challenges and in the worst scenario, both.
The moderating variable career adaptability had four dimensions and four different sub-scales were used for each dimension, namely concern, control, curiosity and confidence, all with six items each (total of 24 items). The mentioned scales were originally developed and validated by Savickas and Porfeli (2012). They are all measured by a five-point Likert scale codified 1-5, signifying 'strongly disagree' to 'strongly agree', respectively. In this study, the reliability score of the mentioned sub-scales was observed to be 0.64 for concern, control (0.72), curiosity (0.74) and 0.74 for confidence.

\section{Data collection and analysis}

Self-administered questionnaires were distributed in rural public schools in the Buffalo City Metropolitan Municipality (BCMM) and a sample of 250 public educators was targeted. Of the questionnaires returned, 214 were deemed usable. The sample consisted of teachers based in schools in the BCMM of which $46 \%$ were male and $54 \%$ were female. In addition, amongst those who participated in the study, 25\% were below the age of $30,33 \%$ were in the $31-40$ years' age range, $36 \%$ were in the $41-50$ years' category and $6 \%$ were in the above 51 years' category.

The authors relied heavily on fieldworkers who issued and collected the questionnaires. To simplify the data collection process, with the help of school principals, fieldworkers were chosen amongst villagers who resided in the same area where each school is located. This made it easier for the fieldworkers to make follow-up visits and remind educators to fill in distributed questionnaires within the agreed length of time, which was five working days.

The researchers applied for an ethical clearance certificate from the institution of higher learning where they are attached as this study involved human participants. Ethical clearance certificate with reference number CH1151SHAR01 was granted. On the ground, respondents were informed of their rights, which also were clearly stated on the questionnaire cover page. The rights emphasised and included that of willingness to participate in the study. After explaining the rights of the participants and the goals of the research, consent of the participants was sought and obtained. To analyse data, the Statistical Package for Social Sciences (SPSS) version 25 was used as a statistical analysis tool. Statistical techniques used include the simple linear regression with respect to $\mathrm{H} 1$ and $\mathrm{H} 2$. Concerning $\mathrm{H} 3$ and $\mathrm{H} 4$, hierarchical regression analysis was utilised.

\section{Ethical consideration}

Ethical clearance was obtained from the University of Fort Hare's Research Committee. Ethical Clearance was received on 28 October 2016 (reference number CHI151SHAR01). 


\section{Results}

\section{Work resources predict employee mental health}

The independent variable data (work resources) and the dependent variable data (mental health) were subjected to a normality test using the Shapiro-Wilk's test and the results reveal a $p$-value of less than 0.001 . This result indicates that the data violated the assumptions of normality, hence to test the stated hypothesis, a simple linear regression analysis with bootstrapped confidence interval (CI) and coefficients was requested, as this type of analysis does not rely on assumptions of normality and homoscedasticity. The results are outlined in Table 1.

Results in Table 1 indicate a weak but positive correlation between work resources and employee mental health, $r=0.345$. The results also indicate that work resources account for $11.9 \%$ of the variation in employee mental health, $R^{2}=0.119$. This result indicates that to better understand the concept of employee mental health, it is worth paying attention to the concept of work resources.

To determine whether the study's model is significantly better at predicting employee mental health, the F-ratio was observed, $F=28.56$ and significant, $p=0.001$. This result informs us that the study's model is useful when predicting employee mental health. Estimates of the model parameters were observed, $b_{0}=18.40$ and $b_{1}=0.357$. See Table 2 for an outline of the results.

The results found and displayed in Table 2 indicate that with unit change in work resources, a corresponding positive change in employee mental health equal to 0.357 units will follow suit. This change is significant, $p=0.001$.
Given this result, the study fails to reject the hypothesis stating that work resources predict employee mental health as there is enough evidence to back this claim.

\section{Work resources predict employee physical health}

The explanatory variable data (work resources) and the outcome variable data (physical health) were investigated to determine whether they violated the assumptions of normality using the Shapiro-Wilk's test. The results indicate that the data violated the assumptions of normality given $p=0.001$. With this result, the simple linear regression analysis was performed and bootstrapped. Confidence intervals and coefficients were requested as these do not rely on assumptions of normality and homoscedasticity. The results are outlined in Table 3.

The results reveal a very weak positive correlation between work resources and employee physical health, $r=0.137$. The results further reveal that work resources only account for $1.9 \%$ of the variation in employee physical health, $R^{2}=0.019$, indicating that approximately $98 \%$ of the variation in employee physical health is accounted for by other factors not in this model. To determine whether the model is significantly better at predicting employee physical health, the F-ratio was observed, $F=4.06$ and significant, given $p=0.045$. Table 4 reveals the estimates of the model parameters. Estimates of the model parameters were observed, $b_{0}=25.91, b_{1}=0.127$.

The result in Table 4 indicates that given a unit change in work resources, there is a positive corresponding change in employee physical health equivalent to 0.127 units and

TABLE 1: Simple linear regression model fit and summary for work resources on employee mental health.

\begin{tabular}{|c|c|c|c|c|c|c|c|c|c|}
\hline Source & $d f$ & Sum of squares & Mean square & $F$ & $\operatorname{Pr}>\mathrm{F}$ & $r$ & $R^{2}$ & Adjusted $R^{2}$ & Estimated standard error \\
\hline Model summary & - & - & - & - & - & 0.345 & 0.119 & 0.115 & 4.03 \\
\hline Regression & 1 & 462.716 & 462.716 & 28.559 & $0.000 *$ & - & - & - & - \\
\hline Residual & 212 & 3434.854 & 16.202 & - & - & - & - & - & - \\
\hline Total & 213 & 3897.570 & - & - & - & - & - & - & - \\
\hline
\end{tabular}

Note: Predictors: Work resources. Outcome variable: Mental health.

$*$, Significant fit at $p<0.05$.

TABLE 2: Parameter estimates for work resources on employee mental health.

\begin{tabular}{|c|c|c|c|c|}
\hline \multirow[t]{2}{*}{ Parameter } & \multicolumn{3}{|c|}{ Unstandardized co-efficient } & \multirow[t]{2}{*}{$95.0 \% \mathrm{Cl}$ for B: LB \& UB } \\
\hline & B & Standard error & Significance & \\
\hline Constant & 18.40 & 1.7 & $0.000 *$ & [15.048-21.75] \\
\hline Work resources & 0.357 & 0.067 & $0.000 *$ & {$[0.225-0.489]$} \\
\hline
\end{tabular}

Note: Predictor: Work resources. Outcome variable: Mental health.

$*$, Significant fit at $p<0.05$.

LB, lower bound; UB, upper bound.

TABLE 3: Simple linear regression model fit and summary for work resources on employee physical health

\begin{tabular}{|c|c|c|c|c|c|c|c|c|c|}
\hline Source & $d f$ & Sum of squares & Mean square & $F$ & $\mathrm{Pr}>\mathrm{F}$ & $r$ & $R^{2}$ & Adjusted $R^{2}$ & Estimated standard error \\
\hline Model summary & - & - & - & - & - & 0.137 & 0.019 & 0.014 & 3.81301 \\
\hline Regression & 1 & 59.030 & 59.030 & 4.060 & $0.045^{*}$ & - & - & - & - \\
\hline Residual & 212 & 3082.278 & 14.539 & - & - & - & - & - & - \\
\hline Total & 213 & 3141.308 & - & - & - & - & - & - & - \\
\hline
\end{tabular}

Note: Predictor: Work resources. Outcome variable: physical health.

$*$, Significant fit at $p<0.05$. 
this change is significant, given $p=0.045$. Given this outcome, the study fails to reject the hypothesis stating that work resources predict employee physical health as there is enough evidence to back this claim.

\section{Career adaptability, work resources and employee mental health}

Hierarchical regression analysis was performed and career adaptability was entered as a moderating variable, work resources as an explanatory variable and employee mental health as an outcome variable. Row 1-8 of Table 5 summarises the results in this regard. The results reveal a negative non-significant relationship between work resources and employee mental health, $b=-0.015,95 \%$ CI $[-0.036,0.006]$, $t=-1.393, p=0.165$. This result indicates that career adaptability does not moderate the relationship between work resources and employee mental health. Given this result, the study rejects the hypothesis stating that career adaptability moderates the relationship between work resources and employee mental health.

\section{Career adaptability, work resources and employee physical health}

Hierarchical regression analysis was performed with career adaptability being the moderating variable, work resources as the independent variable and employee physical health as the dependent variable. Row $9-15$ of Table 5 provides a summary of the results in this regard. The results reveal a non-significant negative relationship between work resources and employee physical health, $b=-0.017,95 \%$ CI $[-0.037$, 0.003], $t=-1.716, p=0.088$. Conditional effects of the focal predictor at the values of the moderator indicate that given the low value of career adaptability equal to -4.622 , a nonsignificant negative relationship between work resources and employee physical health is observed, $b=-0.077,95 \%$ CI $[-0.259,0.104], t=-0.838, p=0.403$. When the score of career adaptability is increased to -1.622 , a negative

TABLE 4: Parameter estimates for work resources on employee physical health.

\begin{tabular}{lcccc}
\hline Parameter & \multicolumn{3}{c}{ Unstandardized co-efficient } & $\begin{array}{c}95.0 \% \text { Cl for B: } \\
\text { LB \& UB }\end{array}$ \\
\cline { 2 - 3 } Constant & B & Standard error & Significance & \\
Work resources & 25.910 & 1.610 & $0.000 *$ & {$[22.74-29.08]$} \\
\hline
\end{tabular}

Note: predictor: Work resources. Outcome variable: Physical health.

*, Significant fit at $p<0.05$

LB, lower bound; UB, upper bound. non-significant relationship between work resources and employee physical health is observed, $b=-0.128,95 \% \mathrm{CI}$ $[-0.281,0.024], t=-1.662, p=0.098$.

When the value of career adaptability is further increased to 4.379 , a significant negative relationship between work resources and employee physical health is observed, $b=-0.231,95 \%$ CI $[-0.387,-0.074], t=-2.908, p=0.004$. The conditional effects of the focal predictor at values of the moderator reveal that with a high score of career adaptability, the relationship between work resources and employee physical health is weaker.

Similar results are confirmed by the Johnson-Neyman method which reveals the significance regions at the level of the moderator. The Johnson-Neyman method reveals that the lower significance cut-off boundary is when career adaptability score is -0.571 , where a significant negative relationship between work resources and employee physical health is observed, $b=-0.146,95 \%$ CI $[-0.293$, 0.000], $t=-1.971, p=0.05$. A weaker negative significant relationship between work resources and employee physical health, $b=-0.470,95 \% \mathrm{CI}[-0.834,0.102], t=-2.518$, $p=0.01$ is further observed at the highest score of career adaptability. Given this result, the study rejects the hypothesis stating that career adaptability moderates the relationship between work resources and employee physical health. A summary of linear model predictors of employee mental and physical health is outlined in Table 5.

\section{Discussion}

The study aimed at investigating the influence of career adaptability on the relationship between work resources and employee health facets such as physical and mental health. Based on the findings of this study, work resources are argued to be the key in promoting employee mental health as the results reveal that work resources account for $11.9 \%$ $\left(R^{2}=0.119\right)$ of the variation in employee mental health. In that regard, H1 which pointed out that work resources predict employee mental health was supported, $p=0.001$. Although work resources accounted for a marginal variation on employee physical health, 1.9\%, $\mathrm{H} 2$ stating that work resources predict employee physical health was supported, $p=0.045$. The study's findings support research

TABLE 5: Linear model of predictors of employee mental and physical health.

\begin{tabular}{|c|c|c|c|c|c|c|}
\hline Linear model predictors & $b$ & $\mathrm{LLCl} \& \mathrm{ULCl}$ & SE B & $t$ & $p$ & $R^{2}$ \\
\hline Employee mental health & - & - & - & - & - & 0.27 \\
\hline Constant & 27.57 & [26.99-28.14] & 0.29 & 95.0 & 0.000 & - \\
\hline Career adaptability & 0.42 & {$[0.29-0.55]$} & 0.07 & 6.39 & 0.000 & - \\
\hline Work resources & 0.07 & {$[-0.08-0.23]$} & 0.08 & 0.91 & 0.37 & - \\
\hline Career adaptability * work resources & -0.015 & {$[-0.04-0.01]$} & 0.01 & -1.39 & 0.165 & - \\
\hline Employee physical health & - & - & - & - & - & 0.21 \\
\hline Constant & 29.34 & {$[28.81-29.88]$} & 0.27 & 108.20 & 0.000 & - \\
\hline Career adaptability & 0.42 & {$[0.30-0.54]$} & 0.06 & 6.93 & 0.000 & - \\
\hline Work resources & -0.156 & {$[-0.30--0.01]$} & 0.07 & -2.13 & 0.034 & - \\
\hline Career adaptability * work resources & -0.017 & {$[-0.040-0.003]$} & 0.01 & -1.72 & 0.088 & - \\
\hline
\end{tabular}

$\mathrm{LLCl}$, lower level of confidence interval; ULCI, upper lever of confidence interval; SE, standard error. 
that emphasised on the importance of work resources on employee mental and physical health (Guo et al., 2017; Haider et al., 2015). Further, these findings may validate the notion that work resources serve a dual utility role within the organisation, affecting facets of employee health. This becomes important especially within the public service, noted to be in a state of flux (Fihla \& Chinyamurindi, 2018) and especially, within the teaching profession in rural South Africa. We can assume that the absence of work resources ultimately affects the quest for service delivery, since it affects those factors in carrying out service to the public. The research results do not dispute existing research regarding the importance of career adaptability in dealing with work and work condition changes. What the results reveal is that work resources, that is adequate salary, performance bonus, medical aid and satisfactory retirement packages amongst others, contribute significantly to rural educators' sound mental and physical health as proposed by $\mathrm{H} 1$ and $\mathrm{H} 2$. In other words, any negative changes in the mentioned work resources, career adaptability resources, that is concern, control, curiosity and confidence will play very little or no role in helping the rural educator in South Africa regain sound mental and physical health. Thus, this research proffers a contribution through illustrating additional components of public service delivery. This contribution advances work that is already on the ground within the South African public service (Ijeoma et al., 2013; Shibiti, 2019; Zondo, 2018). Whilst this work shows support to previous similar international research (Cummins, 2000; Guo et al., 2017), it becomes the first to proffer these findings from a South African public service context. This gains significance since it concerns the challenges, especially of mental health, within the South Africa context (Chinyamurindi, 2019), and its potential impact on the organisation and its employees (Cooper, 2013).

Despite no support being found for the moderation of career adaptability, we support the framing of this construct as a significant faculty in the contemporary world of work (Maree, 2017). The absence of support for career adaptability as a moderator of the relationship between work resources and employee health could indicate that maybe public service employees may value other career issues outside adaptability, which may warrant further inquiry.

\section{Practical implications}

Some practical implications can be drawn from this study. Firstly, given the positive effect that work resources have on employee health, that is mental and physical health, we advocate certain interventions. First, there is a need to buttress and equip the public service with ample work resources as those shown in this work, linking it to employee health. This can be through an audit of the current resources that exist and then improving on the situation. The list of work resources identified in the extant literature can be useful in this audit (Hobfoll, 1989, 2002). In the context of this study, we give precedence to work resources in the form of finance-related gains (salary, bonus, retirement packages and health insurance, amongst others). Studies such as Cummins (2000), Guo et al. (2017), Odle-Dusseau et al. (2019) and Meuris and Leana (2018) emphasised the importance of finance-related work resources to employee well-being. Secondly, given the findings, there is also a need to have a supportive work environment (Watson, 2009) that assists employees in the way they utilise their resources for organisational functioning and also in a way that is friendly to their health. Despite no support being shown for the moderation of career adaptability, there is a need to safeguard the organisation's policies that assist aspects of career development, such as career well-being and efforts toward promoting employee health aspects, such as physical and mental health. A starting point could be to promote a workplace that promotes elements of well-being (Cañibano, 2019), which our work shows, may be achieved by promoting physical and mental health through work resources. Further, given the sample we utilised, there is a need to re-visit aspects of remuneration and working conditions that can be critical especially for public service employees such as teachers.

\section{Limitations and recommendations}

Some limitations can be noted from this study. We acknowledge the challenges of obtaining a reliable sampling frame of rural teachers. Despite our efforts of using fieldworkers, this still proved to be challenge bearing in mind issues of accessibility because of the terrain. As a result of this, we advise caution whilst interpreting the findings. Further, issues of generalisability must be taken into consideration. Future research may overcome this handicap by obtaining a reliable sampling frame not just within the Eastern Cape Province of South Africa but at a national scale. This becomes important given the scale and numerous obstacles in addressing issues of employee health especially in the public service. In our study, we utilised self-report measures, which may potentially result in issues of social desirability bias. Future research could also utilise qualitative research methods to capture the ensuing complexity that can arise out of career adaptability as a processual activity including the role of work resources' spirituality in such processes. Related to this, a need may exist to conduct research with managers in the public service to also get a response from the other side. This can help to ascertain how - from a management perspective - work resources issues are addressed and also assess the response to the challenge of employee health.

\section{Conclusion}

Given the challenges faced within the South African public service that ultimately affect service delivery, a need exists to continuously find ways to ensure bottlenecks to these challenges are addressed. One key issue that needs attention concerns aspects related to employee health. We argue that employee health should be an ongoing conversation in the workplace that is not only enduring but the key to ensuring a reliable and efficient workforce. In doing this, organisations 
like those in the public service should be constantly encouraging and seeking ways to address the matter - ways that are not only cognisant of health-related issues but those that put employees at the forefront. This becomes important for ensuring both performance and efficient service delivery.

\section{Acknowledgements}

The authors acknowledge the work done by field workers and the willingness of educators in rural areas near East London to participate in this study.

\section{Competing interests}

The authors declare that they have no financial or personal relationships that may have inappropriately influenced them in writing this article.

\section{Authors' contributions}

H.S. and W.T.C. conceptualised the study, contributed to the design and implementation, analysis of the results and writing of the manuscript.

\section{Funding information}

The authors acknowledge funding from the South African Medical Research Council. This funding is appreciated and aided the research process. The authors also thank the respondents of the study for giving up their time to take part in this important survey.

\section{Data availability}

The data that support the findings of this study are available from the corresponding author, H.S., upon reasonable request.

\section{Disclaimer}

The views and opinions expressed in this article are those of the authors and do not necessarily reflect the official policy or position of any affiliated agency of the authors.

\section{References}

Abeles L.R. (2009). Absenteeism among teachers: Excused absence and unexcused absence. International Journal of Education Administration, 1(1), 31-49.

Avgoustaki, A., \& Frankort, H.T. (2019). Implications of work effort and discretion for employee well-being and career-related outcomes: An integrative assessment. ILR Review, 72(3), 636-661. https://doi.org/10.1177/0019793918804540

Ballet, K., Kelchtermans, G., \& Loughran, J. (2006). Beyond intensification towards a scholarship of practice: Analysing changes in teachers' work lives. Teachers and Teaching: Theory and Practice, 12(2), 209-229. https://doi. and Teaching: Theory and Pra
org/10.1080/13450600500467415

Barling, J., Dupré, K.E., \& Kelloway, E.K. (2009). Predicting workplace aggression and violence. Annual Review Psychology, 60, 671-692. https://doi.org/10.1146/ annurev.psych.60.110707.163629

Becchetti, L., Bruni, L., \& Zamagni, S. (2015). Human values, civil economy, and subjective well-being (pp. 132-151). World Happiness Report, No. 2015. New York: United Nations Sustainable Development Solutions Network (SDSN)

Bennell, P. (2004). Teacher motivation and incentives in sub-Saharan Africa and Asia. Brighton: Knowledge and Skills for Development. Retrieved from http://eldis.org/ go/home\&id=15756\&type=Document

Bhave, D.P., \& Lefter, A.M. (2017). The other side: Occupational interactional requirements and work-home enrichment. Academy of Management Journal, 61(1), 139-164. https://doi.org/10.5465/amj.2016.0369
Bondarouk, T., Parry, E., \& Furtmueller, E. (2017). Electronic HRM: Four decades of research on adoption and consequences. The International Journal of Human Resource Management, 28(1), 98-131. https://doi.org/10.1080/09585192.2016.1245672

Boyd, N.M., \& Nowell, B. (2020). Sense of community, sense of community responsibility, organizational commitment and identification, and public service motivation: A simultaneous test of affective states on employee well-being and engagement in a public service work context. Public Management Review, 22(7), engagement in a public service work context. Public Management
1024-1050. https://doi.org/10.1080/14719037.2020.1740301

Cañibano, A. (2019). Workplace flexibility as a paradoxical phenomenon: Exploring employee experiences. Human Relations, 72(2), 444-470. https://doi.org/ 10.1177/0018726718769716

Chege, A.W. (2016). The influence of employee benefits on retention at Safari.com limited. Doctoral dissertation. Nairobi: University of Nairobi.

Chinyamurindi, W.T. (2019). Mental health research in African organisations: Advancing theory and practice. South African Journal of Industrial Psychology, 45 1. https://doi.org/10.4102/sajip.v45i0.1727

Chung, H., \& Tijdens, K. (2013). Working time flexibility components and working time regimes in Europe: Using company-level data across 21 countries. The International Journal of Human Resource Management, 24(7), 1418-1434. https://doi.org/10.1080/09585192.2012.712544

Cleeland, C.S., \& Ryan, K.M. (1994). Pain assessment: The global use of the Brief Pain Inventory. Annals Academy of Medicine Singapore, 23(2), 129-138.

Cooke, F.L. (2018). Concepts, contexts, and mindsets: Putting human resource management research in perspectives. Human Resource Management Journal, 28(1), 1-13. https://doi.org/10.1111/1748-8583.12163

Cooper, C. (2013). The future of stress and health research. Stress and Health, 29(5), 349-350. https://doi.org/10.1002/smi.2544

Cummins, R.A. (2000). Personal income and subjective well-being: A review. Journal of Happiness Studies, 1, 133-158. https://doi.org/10.1023/A:1010079728426

De Vos, A., Van der Heijden, B.I., \& Akkermans, J. (2020). Sustainable careers: Towards a conceptual model. Journal of Vocational Behaviour, 117, 1-13. https://doi. org/10.1016/j.jvb.2018.06.011

Deci, E.L., \& Ryan, R.M. (1985). Intrinsic motivation and self-determination in human behaviour. New York, NY: Plenum.

Ejere, I.E. (2010). Absence from work: A study of teacher absenteeism in selected primary schools in Uyo, Nigeria. International Journal of Business and Management, 5(9), 39-53. https://doi.org/10.5539/ijbm.v5n9p115

Esau, O. (2013). Preparing pre-service teachers as emancipatory and participatory action researchers in a teacher education programme. South African Journal of Education, 33(4), 1-10. https://doi.org/10.15700/201412171327

Fieseler, C., Bucher, E., \& Hoffmann, C.P. (2019). Unfairness by design? The perceived fairness of digital labour on crowd working platforms. Journal of Business Ethics, 156(4), 987-1005. https://doi.org/10.1007/s10551-017-3607-2

Fihla, S., \& Chinyamurindi, W. (2018). Human resources management practices on employee commitment: The case of a local municipality in South Africa. Journal of Public Administration, 53(2), 215-233.

Fisher, C.D. (2010). Happiness at work. International Journal of Management Reviews, 12(4), 384-412. https://doi.org/10.1111/j.1468-2370.2009.00270.x

Flum, H., \& Blustein, D.L. (2000). Reinvigorating the study of vocational exploration: A framework for research. Journal of Vocational Behaviour, 56(3), 380-404. https://doi.org/10.1006/jvbe.2000.1721

Fountaine, T., McCarthy, B., \& Saleh, T. (2019). Building the Al-powered organization technology isn't the biggest challenge, culture is. Harvard Business Review, 97(4), 62-73.

Ginevra, M.C., Magnano, P., Lodi, E., Annovazzi, C., Camussi, E., Patrizi, P. \& Nota, L. (2018). The role of career adaptability and courage on life satisfaction in adolescence. Journal of Adolescence, 62, 1-8. https://doi.org/10.1016/j adolescence.2017.11.002

Greenhaus, J.H., \& Powell, G.N. (2006). When work and family are allies: A theory of work-family enrichment. Academy of Management Review, 31(1), 72-92. https:// doi.org/10.5465/amr.2006.19379625

Guo, L., Baruch, Y., \& Russo, M. (2017). Work resources and civic engagement: Benefits to employee physical and mental health. Journal of Vocational Behaviour, 100 56-66. https://doi.org/10.1016/j.jvb.2017.02.007

Haider, M., Rasli, A., Akhtar, C.S., Yusoff, R.B.M., Malik, O.M., Aamir, A., \& Tariq F. (2015). The impact of human resource practices on employee retention in the telecom sector. International Journal of Economics and Financial Issues, 5(1S), 63-69

Hakanen, J.J., Bakker, A.B., \& Schaufeli, W.B. (2006). Burnout and work engagement among teachers. Journal of School Psychology, 43(6), 495-513. https://doi. org/10.1016/j.jsp.2005.11.001

Hakanen, J.J., Peeters, M.C.W., \& Perhoniemi, R. (2011). Enrichment processes and gain spirals at work and at home: A 3-year cross-lagged panel study. Journal of Occupational and Organizational Psychology, 84(1), 8-30. https://doi. org/10.1111/j.2044-8325.2010.02014.x

Halbesleben, J.R., Neveu, B., Paustian-Underdahl, J.P., \& Westman, S.C. (2014). Getting to the 'COR': Understanding the role of resources in conservation of resources theory. Journal of Management, 4O(5), 1334-1364. https://doi. org/10.1177/0149206314527130

Hobfoll, S.E. (1989). Conservation of resources: A new attempt at conceptualizing stress. The American Psychologist, 44(3), 513-524. https://doi.org/10.1037/0003066X.44.3.513 
Hobfoll, S.E. (2002). Social and psychological resources and adaptation. Review of General Psychology, 6(4), 307-324. https://doi.org/10.1037/1089-2680.6.4.307

Hoole, C., \& Hotz, G. (2016). The impact of a total reward system of work engagement. South African Journal of Industrial Psychology, 42(1), 1-14. https://doi. org/10.4102/sajip.v42i1.1317

Ijeoma, E., Nzewi, O., \& Sibanda, M. (2013). South Africa's Public Administration for community development. Pretoria: Verity Publishers.

Ilies, R., Ju, H., Liu, Y., \& Goh, Z. (2020). Emotional resources link work demands and experiences to family functioning and employee well-being: The emotional resource possession scale (ERPS). European Journal of Work and Organizational Psychology, 29(3), 1-16. https://doi.org/10.1080/135943 2X.2020.1718655

Jacobs, S., Renard, M., \& Snelgar, R.J. (2014). Intrinsic rewards and work engagement in the South African retail industry. South African Journal of Industrial Psychology, 40(2), 1-13. https://doi.org/10.4102/sajip.v40i2.1195

Jehanzeb, K. (2020). Does perceived organizational support and employee development influence organizational citizenship behaviour? European Journal of Training and Development, 44(67), 637-657. https://doi.org/10.1108/EJTD-022020-0032

Johnston, C.S. (2018). A systematic review of the career adaptability literature and future outlook. Journal of Career Assessment, 26(1), 3-30. https://doi. org/10.1177/1069072716679921

Kanyane, M.H. (2010). Public service delivery issues in question. In K. Kondlo \& M.H. Maserumule (Eds.), The Zuma administration: Critical challenges (pp. 77-94). Pretoria: HSRC Press.

Koen, J., Klehe, U., \& Van Vianen, A.E.M. (2012). Training career adaptability to facilitate a successful school-to-work transition. Journal of Vocational Behaviour 81(3), 395-408. https://doi.org/10.1016/j.jvb.2012.10.003

Kossek, E.E., \& Lautsch, B.A. (2018). Work-life flexibility for whom? Occupational status and work-life inequality in upper, middle, and lower level jobs?
Academy of Management Annals, 12(1), 5-36. https://doi.org/10.5465/ Academy of Manag

Lee, J.Y., Rocco, T.S., \& Shuck, B. (2020). What is a resource: Toward a taxonomy of resources for employee engagement. Human Resource Development Review, 19(1), 5-38. https://doi.org/10.1177/1534484319853100

Lodi, E., Zammitti, A., Magnano, P., Patrizi, P., \& Santisi, G. (2020). Italian adaption of self-perceived employability scale: Psychometric properties and relations with the career adaptability and wellbeing. Behavioral Sciences, 10(5), 82. https://doi. org/10.3390/bs10050082

Macupe, B. (2018). Varsity doesn't prepare us to teach in rural areas. Retrieved from https://mg.co.za/article/2018-01-26-00-varsity-doesnt-prepare-us-to-teach-inrural-areas/

Mafini, C., \& Dlodlo, N. (2014). The relationship between extrinsic motivation, job satisfaction and life satisfaction amongst employees in a public organisation. South African Journal of Industrial Psychology, 40(1), 1-13. https://doi. org/10.4102/sajip.v40i1.1166

Maree, K. (2017). Psychology of career adaptability, employability and resilience. London: Springer.

Mashaba, E.K. (2014). The impact of teacher absenteeism on the effective management of selected schools in district 15, Soshanguve, Gauteng Province. MEd dissertation. Pretoria: Tshwane University of Technology.

Mashaba, E.K., \& Maile, S. (2018). Factors underlying teacher absenteeism in selected schools located in Tshwane West District, South Africa. International Journal of Educational Development, 4(1), 1-24. https://doi.org/10.25159/2312-3540/3785

Mazmanian, M., Orlikowski, W.J., \& Yates, J. (2013). The autonomy paradox: The implications of mobile email devices for knowledge professionals. Organization Science, 24(5), 1337-1357. https://doi.org/10.1287/orsc.1120.0806

Mburu, L.N. (2020). Examining how employee characteristics, workplace conditions and management practices all combine to support creativity, efficiency and effectiveness. International Journal of Business Management, Entrepreneurship and Innovation, 2(1), 52-64. https://doi.org/10.35942/jbmed.v2i1.102

McNall, L.A., Nicklin, J.M., \& Masuda, A.D. (2010). A meta-analytic review of the consequences associated with work-family enrichment. Journal of Business and Psychology, 25, 381-396. https://doi.org/10.1007/s10869-009-9141-1

Meuris, J., \& Leana, C. (2018). The price of financial precarity: Organizational costs of employees' financial concerns. Organization Science, 29(3), 398-417. https://doi. org/10.1287/orsc.2017.1187

Naicker, S.M. (2000). From Apartheid Education to inclusive education: The challenges of transformation. Paper presented at the International Education Summit for a Democratic Society. Detroit, MI: Wayne State University, June 26-28. Retrieved from http://www.wholeschooling.net/WS/WSPress/From $\% 20$ Aparthied $\% 20$ to $\% 20$ Incl\%20Educ.pdf

Odle-Dusseau, H.N., Matthews, R.A., Wayne, J.H., \& Huang, S. (2019). Critical incidents of financial hardship and worker health: A mixed-methods retrospective study. Occupational Health Science, 3(2), 145-165. https://doi.org/10.1007/s41542 019-00042-4

Oginni, B.O., \& Omoyele, S.O. (2018). A study of labour turnover and organisational productivity in the cable industry of Nigeria manufacturing sector. Advances in Social Sciences Research Journal, 5(8), 294-305. https://doi.org/10.14738/ assrj.58.5000

Okeke, C.I.O., \& Dlamini, C.C. (2013). An empirical study of stressors that impinge on teachers in secondary schools in Swaziland. South African Journal of Education, 33(1), 1-12. https://doi.org/10.15700/saje.v33n1a607

Orlikowski, W.J., \& Scott, S.V. (2014). What happens when evaluation goes online? Exploring apparatuses of valuation in the travel sector. Organization Science, 25(3), 868-891.
Otieno, A. (2010). Human resource management: An educational perspective. Retrieved from https://books.google.com.ph/books/about/Human_Resources

Psychogios, A., \& Prouska, R. (2019). Managing people in small and medium enterprises in TURBULENT contexts. London: Routledge.

Pyhältö, K., Pietarinen, J., \& Salmela-Aro, K. (2011). Teacher-working-environment fit as a framework for burnout experienced by Finnish teachers. Teaching and Teacher Education, 27(7), 1101-1110.

Reddy, V. (2010). HSRC study reveals shocking teacher absenteeism. Retrieved from http://www.hsrc.ac.za/factsheet-17.phtm

Reddy, V., Prinsloo, C.H., Netshitangani, T., Moletsane, R., Juan, A., \& Van Rensburg, D.J. (2010). An investigation into educator leave in South African ordinary public schooling system. Cape Town: Human Sciences Research Council.

Redelinghuys, K., \& Rothmann, S. (2020). Exploring the prevalence of workplace flourishing amongst teachers over time. South African Journal of Industria Psychology, 46, 1-7. https://doi.org/10.4102/sajip.v46i0.1764

Reis, H.T., Sheldon, K.M., Gable, S.L., Roscoe, J., \& Ryan, R.M. (2000). Daily wellbeing: The role of autonomy, competence, and relatedness. Personality and Social Psychology Bulletin, 26, 419-435. https://doi.org/10.1177/0146167 200266002

Rossier, J. (2015). Adaptability and life designing. In L. Nota \& J. Rossier (Eds.) Handbook of the life design paradigm: From practice to theory, from theory to practice (pp. 153-167). Göttingen: Hogrefe.

Rossier, J., Ginevra, M.C., Bollmann, G., \& Nauta, L. (2017). The importance of caree adaptability, career resilience, and employability in designing a successful life. In J.G. Maree (Ed.), Handbook of career adaptability, employability, and resilience (pp. 65-84). New York, NY: Springer.

Roth, G., Assor, A., Kanat-Maymon, Y., \& Kaplan, H. (2007). Autonomous motivation for teaching: How self-determined teaching may lead to self-determined learning. Journal of Educational Psychology, 99(4), 761-774. https://doi.org/10.1037/0022 0663.99.4.761

Savickas, M.L. (1997). Career adaptability: An integrative construct for life-span life-space theory. The Career Development Quarterly, 45(3), 247-259. https:// doi.org/10.1002/j.2161-0045.1997.tb00469.x

Savickas, M.L. (2005). The theory and practice of career construction. In S.D. Brown \& R.W. Lent (Eds.), Career development and counseling: Putting theory and research to work (pp. 42-70). Hoboken, NJ: Wiley.

Savickas, M.L. (2013). Career construction theory and practice. In S.D. Brown \& R.W. Lent (Eds.), Career development and counselling: Putting theory and research to work (2nd edn., pp. 147-183). Hoboken, NJ: John Wiley and Sons.

Savickas, M.L., \& Porfeli, E.J. (2012). Career adapt-abilities scale: Construction, reliability, and measurement equivalence across 13 countries. Journal of Vocational Behaviour, 80(3), 661-673. https://doi.org/10.1016/j.jvb. 2012.01.011

Savickas, M.L., Nota, L., Rossier, J, Dauwalder, J.P. Duarte, M.E., Guichard, J., \& Van Vianen, A.E.M. (2009). Life Designing: A paradigm for career construction in the 21th century. Journal of Vocational Behaviour, 75(3), 239-250. https://doi. org/10.1016/j.jvb.2009.04.004

Schachtel, H.J. (1954). The real enjoyment of living. New York, NY: Dutton.

Schoeman, S., \& Mabunda, P.L. (2012). Teaching practice and the personal and socioprofessional development of prospective teachers. South African Journal of Education, 32, 240-254. https://doi.org/10.15700/saje.v32n3a581

Sheldon, K.M., Ryan, R., \& Reis, H.T. (1996). What makes for a good day? Competence and autonomy in the day and in the person. Personality and Social Psychology Bulletin, 22(12), 1270-1279. https://doi.org/10.1177/01461672962212007

Shibiti, R. (2019). Satisfaction with retention factors in relation to job embeddedness of public school teachers. South African Journal Human Resource Management 17, 1-9. https://doi.org/10.4102/sajhrm.v17i0.1161

Skaalvik, E.M., \& Skaalvik, S. (2010). Teacher self-efficacy and teacher burnout: A study of relations. Teaching and Teacher Education, 26(4), 1059-1069. https:// doi.org/10.1016/j.tate.2009.11.001

Statistics South Africa. (2011). Quarterly labour force survey: Quarter 4 (October to December), 2010. Press Statement. Pretoria: Statistics South Africa.

Stead, G.B., \& Watson, M.B. (2017). Career psychology in the South African context. Pretoria: Van Schaik Publishers.

Stone, D.L., \& Dulebohn, J.H. (2013). Emerging issues in theory and research on electronic human resource management (eHRM). Human Resource Management Review, 23(1), 1-5. https://doi.org/10.1016/j.hrmr.2012.06.001

Strydom, L., Nortjé, N., Beukes, R., Esterhuyse, K., \& Van Der Westhuizen, J. (2012) Job satisfaction amongst teachers at special needs schools. South African Journal of Education, 32(3), 255-266. https://doi.org/10.15700/saje.v32n3a582

Tarafdar, M., Beath, C.M., \& Ross, J.W. (2019). Using Al to enhance business operations. Retrieved from https://sloanreview.mit.edu/article/using-ai-toenhance-business-operations/

Ten Brummelhuis, L.L., \& Bakker, A.B. (2012). A resource perspective on the workhome interface: The work-home resources model. The American Psychologist, 67 545-556. https://doi.org/10.1037/a0027974

Thornhill, C., \& Van Dijik, C. (2018). Public administration theory: Justification for conceptualisation. Research articles. School of Public Management and Administration (SPMA). Retrieved from http://hdl.handle.net/2263/14976

Turok, B. (2010). Big business comes to the table. New Agenda: South African Journa of Social and Economic Policy, 37, 8-14. 
Watson, T. (2009). Organizations, strategies and human resourcing. In J.W. Leopold \& L. Harris (Eds.), The strategic managing of human resources (2nd edn.). Harlow: Prentice Hall.

West, J., \& Meier, C. (2020). Overcrowded classrooms - The Achilles heel of South African education? South African Journal of Childhood Education, 10(1) 1-10. https://doi.org/10.4102/sajce.v10i1.617

Wu, W.Y. (1984). Clinical global impression test. Shanghai Mental Health Journal, 2, 9-21.

Xu, C., Gong, X., Fu, W., Xu, Y., Xu, H., Chen, W., \& Li, M. (2020). The role of caree adaptability and resilience in mental health problems in Chinese adolescents. Children and Youth Services Review, 112, 104893. https://doi.org/10.1016/ j.childyouth.2020.104893
Yiga, D., \& Wandega, A. (2010). Primary school absenteeism in the Iganga District of Uganda. A study conducted by the African Network for the prevention and protection against child abuse and neglect (ANPPCAN) Uganda chapter with protection against child abuse and neglect (ANPPCAN) Uganda chapter with suppot from transparency and accountability program (TAP) of the results for uploads/2012/06/ANPPCAN_Uganda_report teacher_absenteeism_2.pd

Zondo, R.W.D. (2018). The influence of a 360-degree performance appraisal on labour productivity in an automotive manufacturing organisation. South African Journal of Economic Management Sciences, 21(1), 1-7. https://doi.org/10.4102/sajems. v21i1.2046

Zwane, T. (2020). The causal effect of education on earnings in urban and rural South Africa: A further update. Demography and Social Economy, 1(39), 79-94. https:// doi.org/10.15407/dse2020.01.079 